\title{
Deteksi Perubahan Suhu Permukaan Menggunakan Data Satelit Landsat Multi-Waktu (Studi Kasus Cekungan Bandung)
}

\author{
Change Detection of Surface Temperature using \\ Multi-Temporal Landsat \\ (Bandung Basin Case Study)
}

\author{
WIDYA NINGRUM DAN IDA NARULITA
}

Pusat Penelitian Geoteknologi, Lembaga IImu Pengetahuan Indonesia widya.ningrum@lipi.go.id

\begin{abstract}
The rapid population growth and development of infrastructure in the Bandung Basin has triggered an uncontrolled land use changes. The changes of land use will impact on land surface temperature distribution. Finally, these changes will give influence on climate. Land surface temperature is one of the important climatic elements in the energy balance. Changes in land surface temperature variations will potentially change other elements of the climate. The purpose of this paper is to obtain and to analyze the changes of surface temperature distribution in Bandung Basin using multi temporal satellite data processing that is Landsat 5 and Landsat 8 in 2005, 2009, 2014 and 2016. Near Infrared Channel (Near Infrared/NIR) and visible wave channels (Visible band) have used to obtain the value Normalized Difference Vegetation Index/NDVI index and Albedo. Land and vegetation emissivity value and thermal band have used to determine land surface temperature. The results showed that the surface temperature distribution of Bandung Basin has been changes characterized by the presence of two hotspot characters i.e. hot areas in urban and hot areas in non-urban area. The area is characterized by decreasing vegetation index values, increasing albedo values and increasing on surface temperature. Land Surface Temperatures average value increased by $1.3^{\circ} \mathrm{C}$. Land surface temperature tends to rise supposed as a result of changes in vegetated area into open area and the build area.
\end{abstract}

Keywords: land surface temperature, normalized difference vegetation index, albedo

\begin{abstract}
ABSTRAK
Pesatnya pertumbuhan penduduk dan perkembangan infrastruktur di Cekungan Bandung telah memicu perubahan tutupan lahan yang tidak terkendali. Perubahan tutupan lahan akan mempengaruhi distribusi suhu permukaan. Hal tersebut pada akhirnya nanti akan mempengaruhi iklim. Suhu permukaan merupakan salah satu unsur iklim yang penting dalam neraca energi. Perubahan variasi suhu permukaan berpotensi mengubah unsur unsur iklim yang lainnya. Tujuan makalah ini adalah untuk mengetahui dan menganalisis perubahan distribusi suhu permukaan di Cekungan Bandung melalui pengolahan data satelit multi waktu yaitu Landsat 5 dan Landsat 8 tahun 2005, 2009, 2014 dan 2016. Kanal Inframerah Dekat (Near Infrared/NIR) dan kanal gelombang tampak (Visible band) digunakan untuk memperoleh nilai Indeks Kehijauan Vegetasi (Normalized Difference Vegetation Index/NDVI) dan Albedo. Nilai emisivitas dari tanah dan vegetasi serta Band termal digunakan untuk menentukan nilai Suhu Permukaan Tanah. Hasil penelitian menunjukkan bahwa di Cekungan Bandung telah terjadi perubahan distribusi suhu permukaan yang dicirikan oleh adanya dua karakter hotspot yaitu daerah panas di daerah urban dan daerah panas di daerah non-urban. Daerah tersebut dicirikan menurunnya nilai indeks vegetasi, menurunnya nilai albedo dan meningkatnya nilai suhu permukaan tanah. Nilai rataan Suhu Permukaan Tanah tahun 2005 - 2016 meningkat sebesar $1.3^{\circ} \mathrm{C}$. Kecenderungan naik ini diduga sebagai akibat adanya perubahan tutupan lahan bervegetasi menjadi daerah yang lebih terbuka dan daerah terbangun.
\end{abstract}

Kata kunci: suhu permukaan, indeks kehijauan vegetasi, albedo 


\section{PENDAHULUAN}

Cekungan Bandung merupakan bagian hulu dari DAS Citarum. Daerah tersebut secara hidrologis telah mengalami kerusakan (degradasi) cukup parah. Kondisi ini sebagai akibat dari penggunaan sumberdaya lahan dan air yang melebihi daya dukungnya. Degradasi lingkungan ini diduga ikut berkontribusi sebagai penyebab terjadinya kondisi ekstrim iklim melalui perubahan suhu permukaan maupun udara(1). Dampak hal tersebut jika terjadi kondisi ekstrim iklim dan fluktuasi iklim maka akan terjadi bencana sumberdaya air dan lahan.

Peningkatan jumlah penduduk yang pesat serta perubahan penggunaan lahan dalam bentuk pengembangan daerah perumahan, industri, pertanian, infrastruktur yang tidak terkontrol diyakini sebagai penyebab utama degradasi lingkungan ini. Peningkatan jumlah penduduk sangat terkait dengan perubahan penggunaan lahan(2). Bangunan, jalan, dan infrastruktur lainnya telah mengubah atau mengganti lahan bervegetasi menjadi lahan terbangun. Permukaan yang dulunya tidak kedap air dan lembab menjadi kedap air dan kering. Suhu permukaan di daerah perkotaan, di daerah non vegetasi menjadi lebih hangat daripada di daerah bervegetasi. Suhu di daerah perkotaan/ urban lebih hangat dan daerah pinggirannya yang merupakan lingkungan bervegetasi/pedesaan, ini membentuk sebuah "pulau" dengan suhu yang lebih tinggi dari sekelilingnya(3,4). Intensitas Pulau Panas ini berhubungan dengan pola penggunaan lahan/perubahan tutupan lahan ${ }^{(5)}$. Adanya pulau Panas ini lebih dikenal dengan Pulau Panas Bahang Perkotaan.

Studi perubahan suhu permukaan akibat perubahan tutupan lahan sangat penting karena suhu permukaan sangat mempengaruhi faktor iklim, kualitas udara, kesehatan manusia dan penggunaan energi. Suhu permukaan pada fenomena Pulau panas bahang perkotaan merupakan salah satu faktor terbesar penyebab perubahan iklim dan global warming(6). Suhu permukaan berhubungan dengan adanya anomali presipitasi konvektif di daerah tropis ${ }^{(7)}$. Pada lingkup lokal, distribusi suhu permukaan tanah dapat menjelaskan dengan baik distribusi suhu permukaan. Studi deteksi perubahan suhu permukaan tanah telah dilakukan oleh Effat ${ }^{(5)}$ tahun 2014 dengan mempertimbangkan faktor emisivitas vegetasi dan tanah ${ }^{(5)}$. Pertimbangan kedua faktor tersebut dapat mengidentifikasi lokasi mikro urban heat island dan titik-titik panas (hotspot) di daerah studi, yaitu di kota Cairo(5).

Suhu permukaan tanah merupakan salah satu unsur yang penting dalam neraca energi. Peran penting suhu permukaan tanah terutama dalam neraca radiasi netto pada permukaan bumi. Pengukuran suhu permukaan tanah dibutuhkan dalam berbagai studi, baik iklim, hidrologi, ekologi, dan biogeokimia ${ }^{(8,9)}$. Peningkatan suhu permukaan tanah akan mempengaruhi cuaca dunia dan pola iklim. Kenaikannya dapat mencairkan gletser dan lapisan es di daerah kutub. Selain itu, peningkatan suhu permukaan juga dapat menyebabkan banjir dan kenaikan muka air laut ${ }^{(10)}$.

Di cekungan Bandung telah terjadi peningkatan suhu permukaan di daerah perkotaan akibat pembangunan perkotaan yang tidak terkendali(11). Studi memetakan distribusi suhu permukaan cekungan Bandung telah dilakukan sebelumnya dengan pengolahan data satelit Landsat 5 dan Landsat 7 ETM. Selain itu telah dilakukan evaluasi yang didasarkan pada WDRVI (Wide Dynamic Range Vegetation Indices), NDBI (Normalized Difference Built-up Index) dan SAVI (Soil-Adjusted Vegetation Index) ${ }^{(11)}$. Hasilnya menunjukkan bahwa daerah urban berkontribusi besar dalam meningkatkan temperatur dan penanaman vegetasi di daerah industri berkontribusi dalam penurunan suhu ${ }^{(11)}$.

Pada makalah ini dilakukan deteksi perubahan suhu permukaan di cekungan Bandung dengan menggunakan pengolahan data citra satelit (Landsat) tahun 2005, 2009, 2014 dan 2016 dengan mempertimbangkan emisivitas vegetasi dan emisivitas tanah(5). Deteksi suhu permukaan dengan mempertimbangkan emisivitas vegetasi dan emisivitas tanah dikenal dengan "Land surface temperature"(5). Dengan memetakan "Land Surface Temperature" akan dapat dianalisis suhu panas perkotaan mikro seperti adanya titik hot spot di daerah perkotaan yang tekanan lingkungan nya masih sedikit ${ }^{(5)}$. Hasil yang diharapkan dari studi ini diketahuinya perubahan/dinamika distribusi suhu permukaan. Selain itu dapat diketahui dan dianalisis lokasi hot spot di cekungan Bandung baik di daerah urban maupun non-urban.

Beberapa parameter yang terkait dengan suhu permukaan akan dianalisis pada makalah ini. Parameter yang dianalisis meliputi distribusi nilai indeks kehijauan vegetasi (Normalized Difference Vegetation Index/NDVI)) dan nilai Albedo. Vegetasi dapat menjadi indikator dari dinamika suhu permukaan. Semakin banyak tutupan vegetasi maka suhu permukaan akan semakin dingin dan sebaliknya(12). Validasi adanya suhu panas di daerah urban bisa dilakukan dengan menggunakan pola nilai indeks kehijauan vegetasi(13). Studi suhu di daerah urban telah lama dilakukan melalui pengamatan dengan menggunakan termometer udara baik yang dipasang di tempat maupun yang bergerak (14). Sejumlah penelitian suhu di daerah urban 
dilakukan dengan menggunakan Landsat TM/ETM Data ASTER + dan inframerah (TIR). Data termal dengan $120 \mathrm{~m}$ dan $60 \mathrm{~m}$ resolusi spasial Landsat Thematic Mapper TM dan ETM +, masing-masing, telah digunakan untuk studi suhu daerah urban skala lokal ${ }^{(15,16)}$. Beberapa jenis algoritma telah dibangun untuk memperoleh suhu permukaan dari citra Landsat diantaranya algoritma mono-window, algoritma singlechannel, dan persamaan transfer radiasi ${ }^{(17)}$. Area perluasan suhu urban di area perkotaan kota Bandung telah teramati berdasarkan data suhu permukaan global tahun $1994-2001^{(18)}$.

Perubahan suhu permukaan disebabkan oleh perubahan vegetasi terutama sebagai akibat dari perubahan albedo ${ }^{(19)}$. Jadi variasi albedo ditentukan oleh perbedaan jenis vegetasi ${ }^{(19)}$. Dalam penelitian ini nilai indeks vegetasi serta nilai albedo akan digunakan sebagai validasi dari nilai suhu permukaan di daerah penelitian.

\section{BAHAN DAN METODE}

\subsection{Daerah Penelitian}

Cekungan Bandung merupakan suatu bentang alam berbentuk cekung, seperti mangkuk. Secara geografis cekungan Bandung berada pada $6,6^{\circ}-7^{\circ}$ LS dan $107,18^{\circ}-107,9^{\circ}$ BT. Lokasi Cekungan Bandung dapat dilihat pada Gambar 1. Cekungan Bandung memiliki iklim pegunungan yang lembab dan sejuk. Suhu udara rata-rata $23.4^{\circ} \mathrm{C}$. Curah hujan rata-rata tahunan sebesar $1988 \mathrm{~mm}$ dengan hari hujan rata-rata 18 hari per bulannya(20). Secara topografi cekungan Bandung terletak pada ketinggian ketinggian $650 \mathrm{~m}$ sampai lebih dari 2000 meter $^{(21)}$. Cekungan Bandung terdiri dari 3 wilayah administratif yaitu: Kota Bandung, Kabupaten Bandung dan Kabupaten Bandung Barat. Sebagian besar wilayah cekungan Bandung merupakan wilayah pegunungan, dengan iklim tropis. Cekungan Bandung mengalami perkembangan pembangunan yang sangat pesat dari tahun ke tahun. Hal ini terkait dengan peran Kota Bandung sebagai ibukota provinsi Jawa Barat. Perkebangan kota yang sangat pesat akan mengakibatkan perubahan lahan yang akan mengakibatkan perubahan komponen iklim yaitu temperatur.

Data yang digunakan dalam makalah ini adalah data Landsat Thematic Mapper (TM) 5 dan Landsat Thermal Infrared Sensor (TIRS) 8 untuk tahun 2005, 2006, 2009 dan 2014. Makalah ini menggunakan beberapa teknik pengolahan data citra yang diaplikasikan untuk studi yaitu menyusun distribusi tingkat kehijauan vegetasi dan hubungannya dengan distribusi temperatur. Kanal optik 1, 2, 3, 4, 5 dan 7 (optical bands: bands 1, 2, 3, 4, 5 and 7) telah digunakan untuk memetakan indeks kehijauan vegetasi dan albedo serta perubahannya. Sedangkan kanal 6 (thermal band) digunakan untuk memetakan suhu permukaan. Beberapa jenis algoritma telah dibangun untuk memperoleh suhu permukaan tanah dari citra Landsat diantaranya algoritma mono-window, algoritma single-channel, dan persamaan transfer radiasi ${ }^{(17)}$.

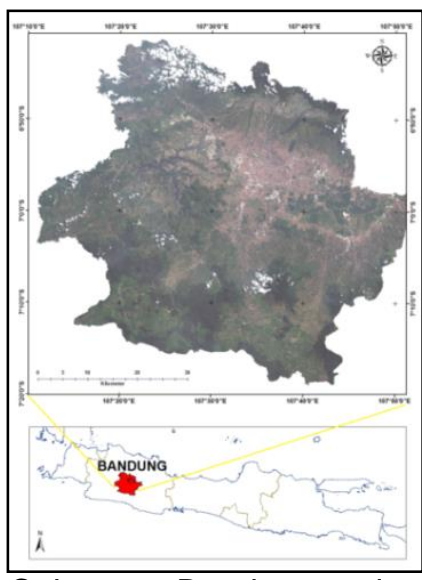

Gambar 1. Cekungan Bandung pada tahun 2013, akuisisi data Landsat 8

\subsection{Deteksi Perubahan Albedo}

Albedo adalah kekuatan pantulan permukaan benda yang merupakan perbandingan antara radiasi surya yang dipantulkan dengan radiasi yang datang ${ }^{(5)}$. Vegetasi berdaun lebar memiliki nilai albedo yang lebih kecil dibandingkan dengan rumput. Lahan terbangun berupa bangunan memiliki albedo paling tinggi. Nilai Albedo diperoleh dari citra Landsat menggunakan formula yang digunakan oleh Smith ${ }^{(22)}$. Albedo memiliki nilai berkisar antara 0 sampai 1.0 dan akan bervariasi berdasarkan tutupan lahan.

$((0.356$ * $\mathrm{B} 1)+(0.13$ * $\mathrm{B} 2)+(0.373$ * $\mathrm{B} 3)+$ $(0.085 *$ B4 $)+(0.072 *$ B5) -0.018$) / 1.016) \ldots .(1)$

Keterangan: B1, B2, B3, B4, B5 adalah band Landsat.

\subsection{Deteksi indeks kehijauan vegetasi (Normalized Difference Vegetation Index (NDVI)}

NDVI menunjukkan tingkat kehijauan suatu vegetasi. NDVI memisahkan vegetasi dari tutupan lainnya karena klorofil menyerap cahaya merah untuk fotosintesis dan merefleksikan panjang gelombang infrared dekat (Near Infrared/NIR) karena hamburan yang disebabkan oleh struktur internal daun ${ }^{(5)}$. NDVI diturunkan berdasarkan persamaan ${ }^{(5,17)}$. 


$$
N D V I=\frac{N I R-V I R}{N I R+V I F}
$$

Keterangan

NIR: Near Infrared; kanal 4 untuk Landsat5, kanal 5 untuk Landsat8,

VIR: Visible Red; kanal 3 untuk Landsat5, kanal 4 untuk Landsat8

\subsection{Menentukan Distribusi temperatur permukaan tanah (Land surface temperature (LST).}

Langkah langkah yang dilakukan didasarkan pada persamaan berikut ini:

\subsubsection{Menentukan Top of Atmospheric Spectral Radiance (TOA)}

Produk Landsat standarnya berupa Digital Numbers (DN) dalam skala yang terukur dan terkalibrasi. Nilai DN ini merepresentasikan nilai piksel dari tiap kanal. DN citra Landsat pada penelitian ini diubah menjadi spectral radiance. Perhitungan untuk kanal termal (band 6) pada Landsat 5 didasarkan pada persamaan yang dikembangkan Chander \& Markham $^{(23)}$ yaitu

$$
L \lambda=0.055158 \times Q c a l+1.2378 .
$$

Sedangkan untuk Landsat 8, nilai TOA diperoleh dari persamaan:

$$
L \lambda=0.000342 * Q c a l+0.1
$$

Keterangan

$\mathrm{L \lambda}$ : Radiansi spectral dari sensor dalam $\mathrm{W} /\left(\mathrm{m}^{2} . \mathrm{sr} . \mu \mathrm{m}\right)$

$\mathrm{Q}_{\mathrm{CAL}}$ : Nilai piksel citra satelit ( $D N /$ digital number).

\subsubsection{Menentukan Suhu Kecerahan/Temperature Brightness (TB)}

Nilai radiansi spectral yang diperoleh selanjutnya dikonversi menjadi suhu kecerahan (TB). Persamaan 4 digunakan untuk mengkonversi nilai spectral radiance menjadi suhu kecerahan $^{(5,23)}$

$$
T B=\frac{K 2}{\ln \left\{\frac{K 1}{L \lambda}+1\right\}}
$$

Keterangan

TB : Brightness Temperature dalam Kelvin,

$\mathrm{K} 1$ : Konstanta kalibrasi dalam $\mathrm{W} /\left(\mathrm{m}^{2}\right.$.sr. $\left.\mu \mathrm{m}\right)$,

K2 : Konstanta kalibrasi dalam Kelvin,

$\mathrm{L} \lambda$ : Spektral Radiansi dalam W/( $\mathrm{m}^{2}$. sr. $\left.\mu \mathrm{m}\right)$.

Tabel 1 memberikan nilai konstanta kalibrasi untuk Landsat 5 dan Landsat 8.

\subsubsection{Menentukan suhu Permukaan Tanah / Land Surface Temperature}

Setelah emisivitas tanah diperoleh, nilai suhu permukaan tanah dapat dihitung berdasarkan persamaan (7)

$$
\begin{gathered}
L S T=\frac{\tau_{B}}{1+\left(\frac{\lambda T_{B}}{p}\right) \ln \varepsilon} . \\
p=\frac{h c}{\delta} \ldots . .
\end{gathered}
$$

Keterangan

$\mathrm{T}_{\mathrm{B}}$ : Brightness Temperature dalam Kelvin,

\begin{tabular}{|c|c|c|c|}
\hline Konstanta & & $\begin{array}{c}\mathrm{K} 1 \\
\mathrm{~W} /\left(\mathrm{m}^{2} . \mathrm{sr} . \mu \mathrm{m}\right)\end{array}$ & $\begin{array}{c}\text { K2 } \\
\text { Kelvin }\end{array}$ \\
\hline Landsat 5 & & 607.76 & 1260.56 \\
\hline \multirow{2}{*}{ Landsat 8} & Band 10 & 1321.08 & 777.89 \\
\hline & Band 11 & 1201.14 & 480.89 \\
\hline
\end{tabular}

$\Lambda$ : Panjang gelombang dari radiasi yang diemisi, $\varepsilon=$ Emisivitas, $\delta=$ Konstanta Boltzmann $-1.38^{*} 10^{-23} \mathrm{~J} / \mathrm{K}$,

h : Konstanta Planck $-6.626^{*} 10^{-34} \mathrm{Js}$,

c : Kecepatan cahaya $-2.998^{\star} 10^{8} \mathrm{~m} / \mathrm{s}$, dan $\mathrm{p}=14380 \mathrm{mK}$.

Tabel 1. Konstanta kalibrasi kanal termal

\subsubsection{Pemetaan Suhu Permukaan Tanah}

Pemetaan Suhu Permukaan tanah dilakukan dengan cara melakukan pemetaan intensitasnya yaitu dengan melihat perbedaan antara rata rata suhu di daerah urban dan daerah pedesaan di

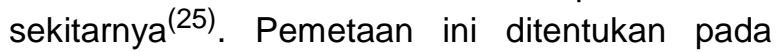
daerah yang mempunyai temperatur permukaan tanah lebih dari $30^{\circ} \mathrm{C}^{(18) \text {. }}$

\section{HASIL DAN PEMBAHASAN}

\subsection{Deteksi Perubahan Albedo}

Nilai albedo di cekungan Bandung terbagi menjadi 4 kelas yaitu: $<0.1 ; 0,11-0,15 ; 0.16-$ 0.2 dan 0.21 - 0.3 (Gambar 1). Variasi nilai albedo tersebut sesuai dengan tutupan lahannya(29). Di cekungan Bandung albedo rendah terdeteksi di badan sungai dan daerah bervegetasi sedangkan daerah urban dan terbangun mempunyai nilai albedo yang lebih tinggi.Hal ini menunjukkan bahwa radiasi pantul di daerah urban lebih tinggi daripada daerah vegetasi. Sedangkan nilai albedo yang lebih besar dari 0.3 dideteksi sebagai awan. 


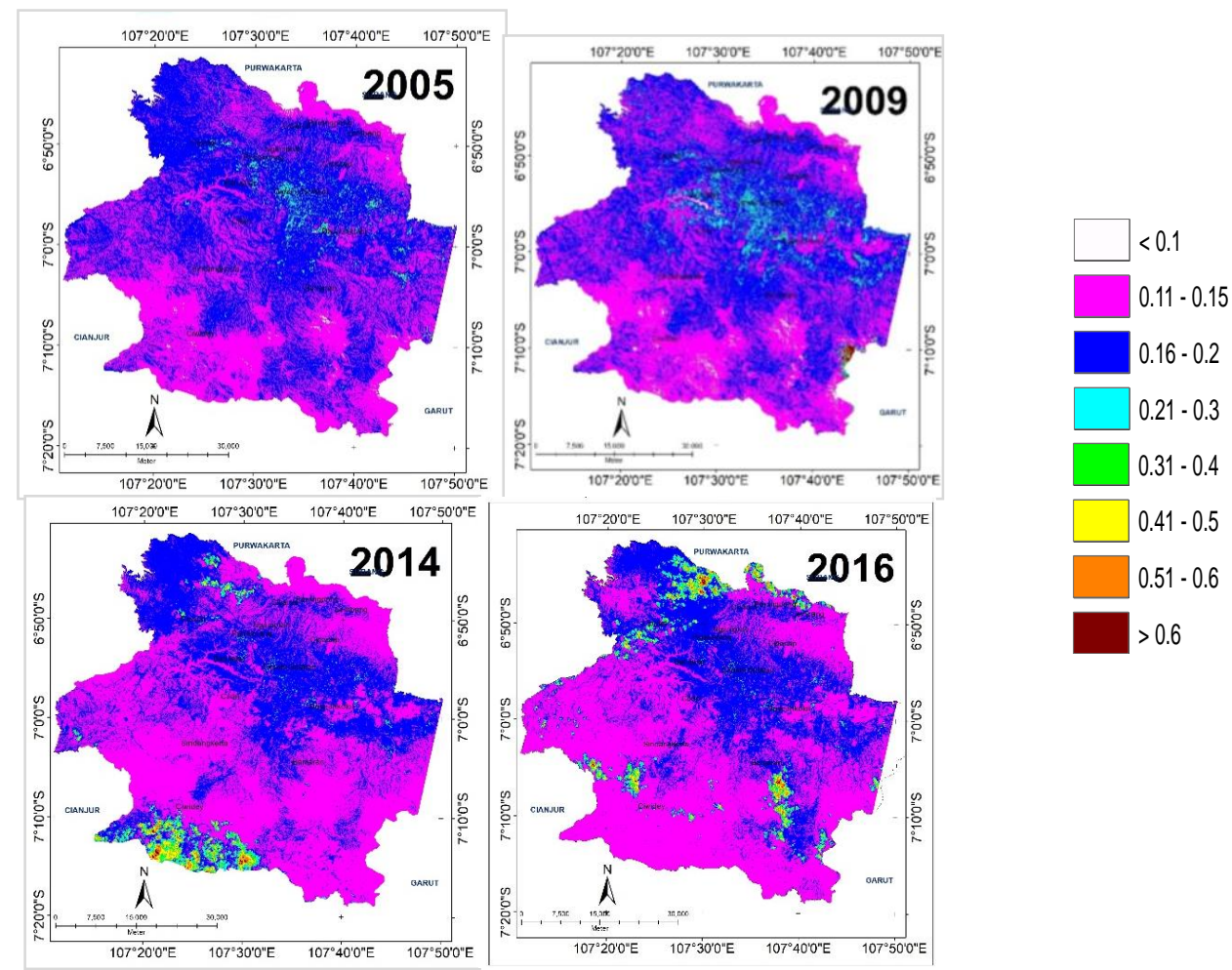

Gambar 1. Sebaran nilai Albedo di cekungan Bandung tahun 2005, 2009, 2014 dan 2016

Albedo awan berkisar antara 0.2 sampai dengan 0.95 dimana albedo awan tinggi akan lebih kecil dibandingkan awan rendah. Hal tersebut dikarenakan awan tinggi akan lebih sedikit memantulkan radiasi gelombang pendek yang datang dibandingkan meneruskannya ${ }^{(30)}$.

Nilai albedo rata rata di cekungan Bandung pada periode 2005 - 2016 menunjukkan kecenderungan naik (Gambar 2). Artinya di cekungan Bandung terjadi kecenderungan perubahan tutupan lahan yang meningkatkan pantulan cahaya matahari, yaitu perubahan daerah bervegetasi menjadi daerah terbangun atau lebih terbuka

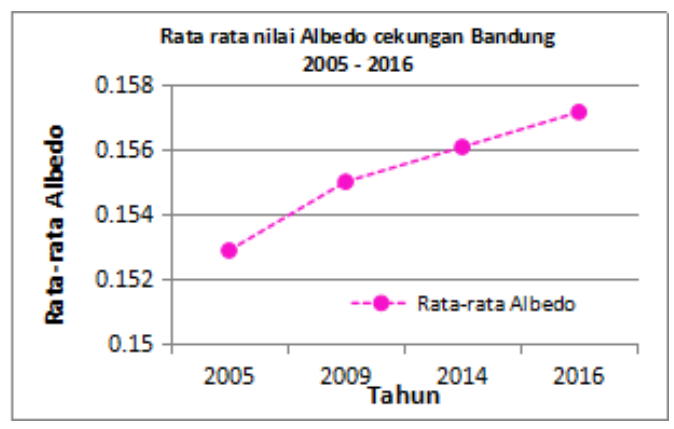

Gambar 2. Nilai Rata-rata Albedo cekungan Bandung 2005 - 2014

\subsection{Deteksi Perubahan indeks kehijauan di cekungan Bandung}

Keberadaan vegetasi pada citra hasil transformasi NDVI ditunjukkan dengan tingkat kehijauan yang berkorelasi dengan tingkat kerapatan vegetasi. Nilai indeks NDVI mendekati 1 menunjukkan bahwa di daerah tersebut memiliki tingkat kerapatan vegetasi yang tinggi. Perubahan pola sebaran tutupan vegetasi di Cekungan Bandung dapat dilihat pada perubahan sebaran nilai indeks kehijauan pada Gambar 3. Nilai NDVI di cekungan Bandung membagi tutupan vegetasinya menjadi empat kelas, termasuk badan air dan tanah terbuka. Warna hijau mencirikan vegetasi dari rumput hingga hutan hujan tropis. Padang rumput dan semak belukar memiliki kisaran nilai NDVI 0.2 0.4 . Nilai NDVI hutan daerah hangat dan hutan hujan tropis berkisar antara 0.4 hingga 1 . Sedangkan warna coklat terang menandakan daerah tersebut merupakan bangunan, batuan, dan tanah terbuka yang tidak ada vegetasi di atasnya dengan rentang nilai NDVI 0 hingga 0.2. Pada tahun 2005 daerah terbangun relatif terpusat di Kota Bandung dan sedikit ke arah Bandung Timur. 


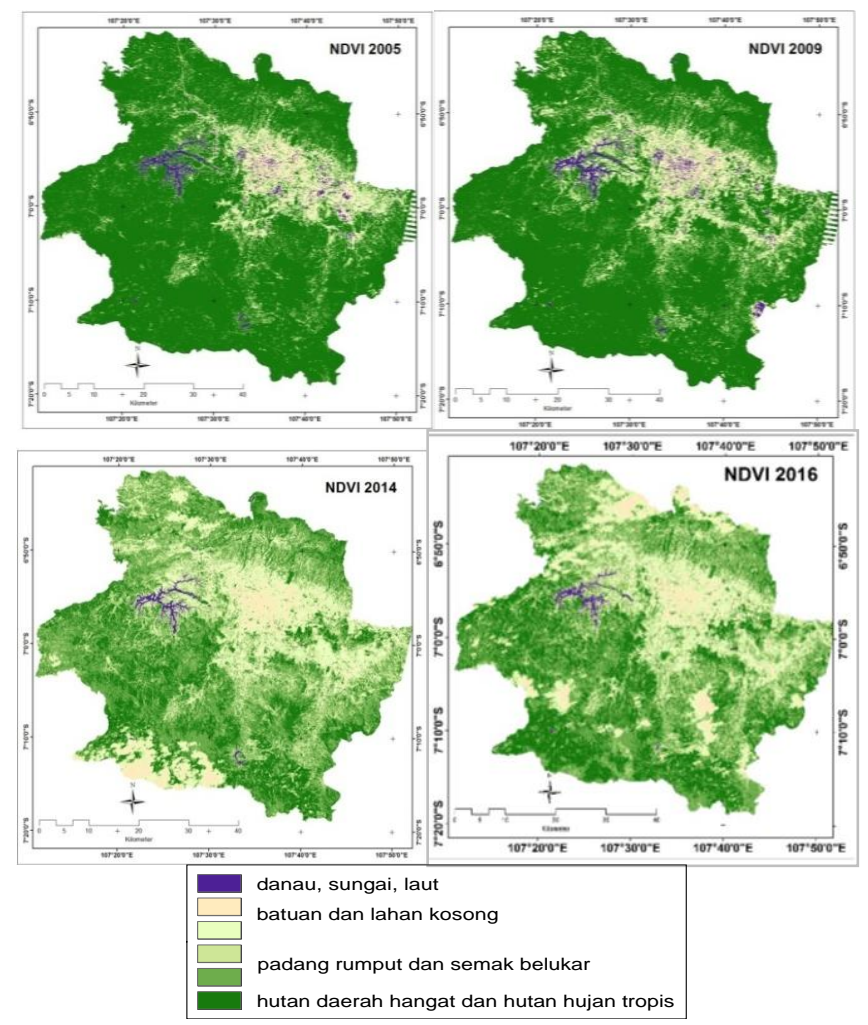

Gambar 3. Sebaran Nilai Indeks Kehijauan Vegetasi di Cekungan Bandung Tahun 2005, 2009, 2014 dan 2016

Pola perkembangan daerah terbangun di daerah perkotaan sejak tahun 2005 menerus meningkat sampai tahun 2014. Pada tahun 2005 berkisar $75 \%$ daerah di cekungan Bandung mempunyai nilai NDVI $0.4-1$, artinya $75 \%$ luasan cekungan Bandung pada tahun 2005 adalah merupakan daerah bervegetasi rapat (hutan). Pada tahun 2009 luasan tutupan lahan hutan mulai berkurang akibat dari perkembangan daerah terbangun di Bandung Timur dan Bandung Utara. Perkembangan daerah terbangun cukup signifikan terjadi pada rentang waktu 2009 - 2014. Pada tahun 2014 luasan dengan nilai kerapatan vegetasi $0.4-1$ (hutan) luasannya berkurang hingga tinggal $23 \%$ saja.

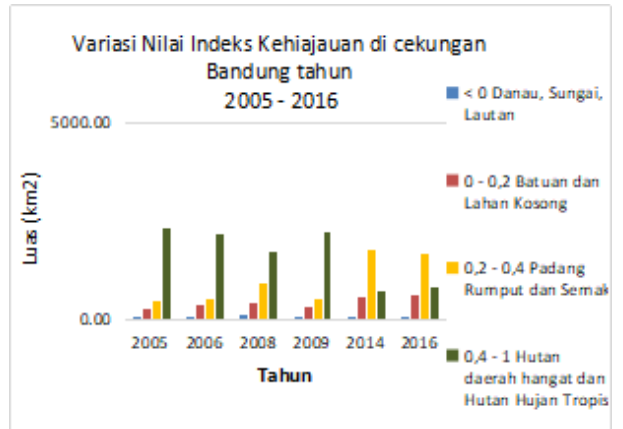

Gambar 4. Grafik variasi nilai indeks kehijauan di cekungan Bandung 2005 - 2016

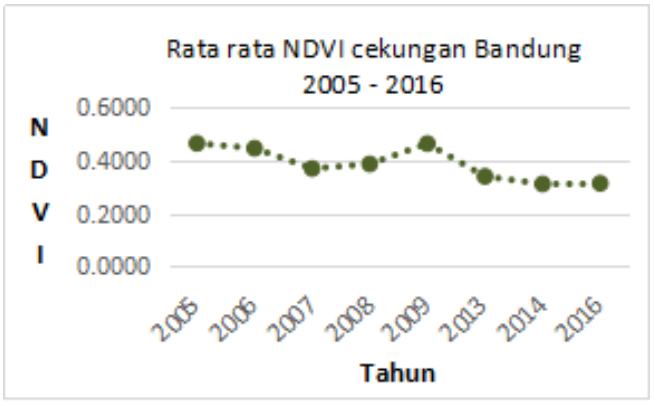

Gambar 5. Grafik Rata-rata nilai variasi indeks kehijauan vegetasi di cekungan Bandung tahun 2005 - 2016

\subsection{Distribusi temperatur permukaan tanah}

Perubahan pola distribusi spasial suhu permukaan tanah dari tahun 2004 sampai dengan tahun 2016 terlihat jelas pada Gambar 6 . Suhu terendah di cekungan Bandung adalah kurang dari $20^{\circ} \mathrm{C}$ yang berada di daerah perbukitan Bandung Utara dan Bandung Selatan. Ada beberapa hot spot dan area panas dengan kelas suhu yang tinggi teridentifikasi. Area panas dengan suhu permukaan tanah tinggi teridentifikasi di pusat kota Bandung, Cimahi dan bagian Tenggara cekungan Bandung. Kisaran suhu permukaan tanah pada tahun 2005 sebesar 7.18-36 ${ }^{\circ} \mathrm{C}$, dan pada tahun 2014 sebesar 10.24$39^{\circ} \mathrm{C}$. Berdasarkan hasil penelitian terlihat bahwa suhu permukaan tanah di daerah Kota Bandung relatif lebih tinggi dibandingkan daerah sekitarnya yang ditunjukkan dengan terpusatnya area panas 
di tengah Cekungan Bandung. Pola khusus persebaran suhu permukaan tanah berkaitan erat dengan karakteristik termal kelas tutupan lahan $^{(5)}$. Pengaruh suhu permukaan terhadap kondisi udara di atasnya terjadi melalui konduksi semu yaitu perpindahan panas pada lapisan udara yang paling dekat dengan permukaan. Selanjutnya terjadi perpindahan panas bersama molekul udara yang bergerak (konveksi) sehingga udara dipanaskan oleh permukaaan bumi akibat radiasi matahari. Proses konveksi ini menyebabkan suatu pola dengan interval suhu udara tinggi di permukaan kota pada tutupan non vegetasi seperti permukiman, lahan terbuka, dan industri. Suhu permukaan tanah yang rendah terdapat di perbukitan Bandung Utara dan Bandung Selatan, dimana suhu permukaan menurun pada tanaman rerumputan, semak, hujan tropis dan badan air (Gambar 6.). Suhu di atas $30^{\circ} \mathrm{C}$ terdeteksi mulai ada pada tahun 2009, yaitu di kota Bandung, Cimahi, Cipatat, dan Bandung Selatan. Pada tahun 2014 area dengan $30^{\circ} \mathrm{C}$ ini mangalami perluasan. Adanya distribusi suhu permukaan yang mencolok antara daerah urban dan daerah non-urban ini memungkinkan terbentuknya pulau panas perkotaan ${ }^{(27)}$. Perhitungan statistik menunjukkan pada rentang waktu 2005-2014 terjadi perubahan distribusi suhu permukaan tanah yaitu adanya kecenderungan kenaikan suhu permukaan tanah rata-rata sebesar $1.3^{\circ} \mathrm{C}$ (Gambar 6.). Kecenderungan kenaikan suhu permukaan tanah ini diakibatkan oleh berkurangnya daerah bervegetasi di cekungan Bandung.

Pada tahun 2016 suhu permukaan tanah turun cukup signifikan. Penurunan ini terkait dengan akuisisi data citra yang digunakan. Data citra tahun 2016 dipotret pada bulan September dimana saat itu sedang musim hujan di cekungan Bandung. Pada saat musim hujan kandungan air di tanah cukup banyak sehingga menurunkan temperatur tanah. Sementara tahun 2005 - 2014 adalah data citra satelit yang di potret pada bulan Juli dimana saat itu musim kemarau. Sehingga data tahun 2016 ini tidak memenuhi syarat untuk dianalisa bersama dengan data-data sebelumnya karena dipotret pada musim yang berbeda.
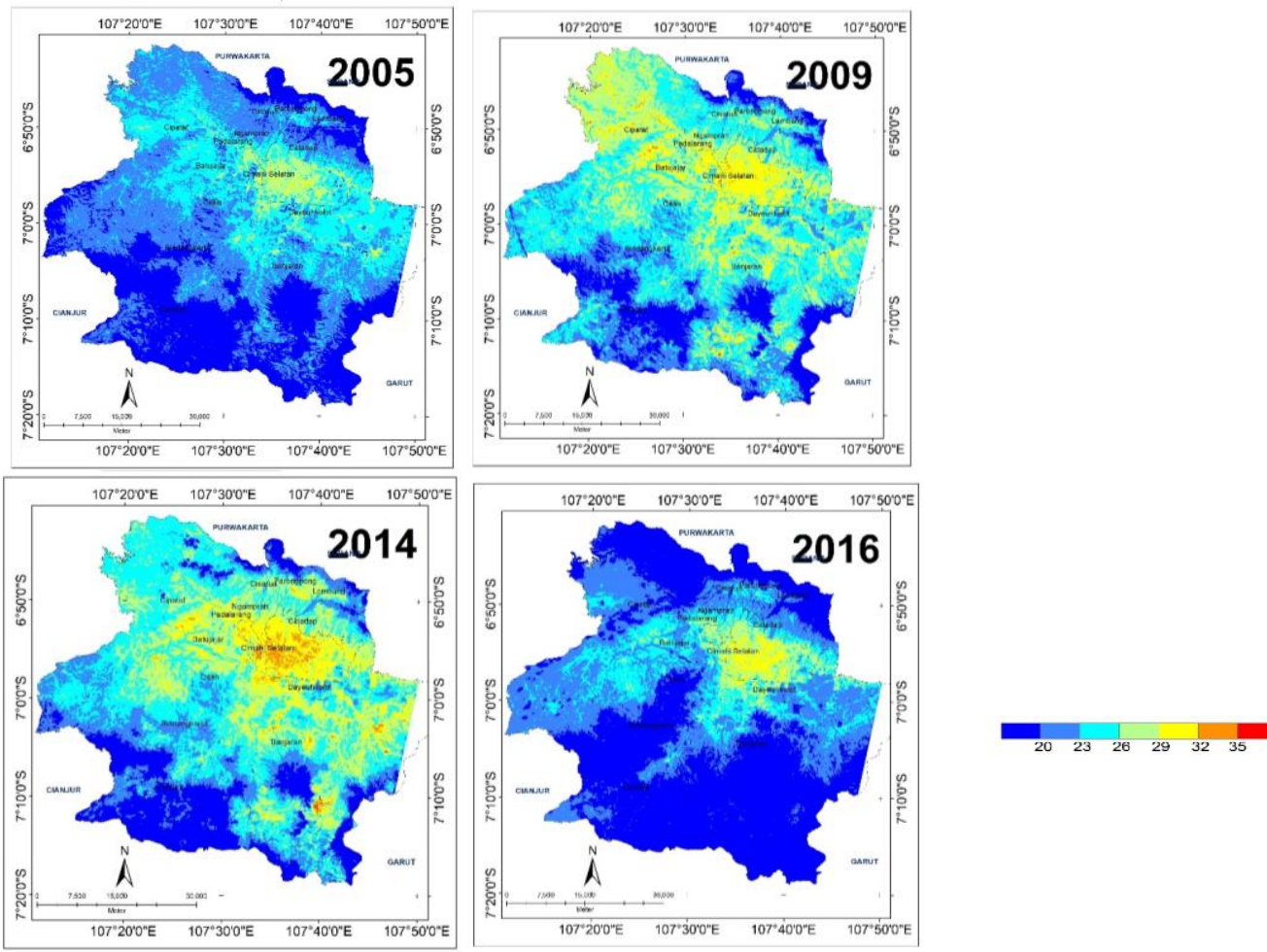

Gambar 6. Suhu Permukaan Tanah yang diturunkan dari data Landsat dari tahun 2005, 2009, 2014 dan $2016^{(28)}$ 


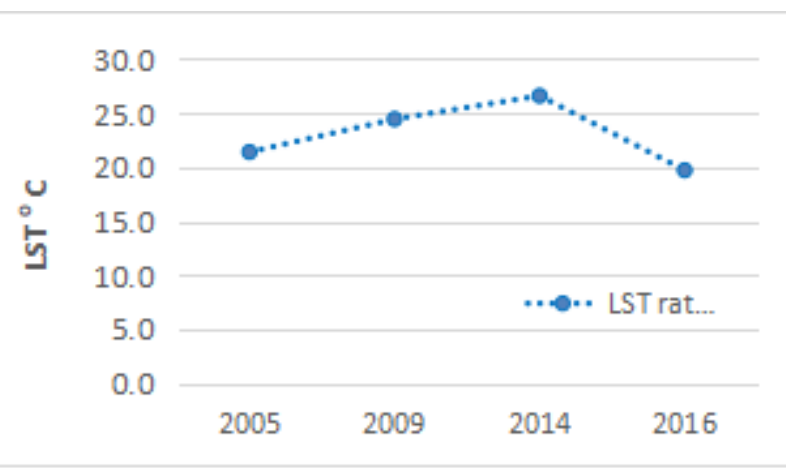

Gambar 7. Nilai Rataan Suhu Permukaan Tanah di Cekungan Bandung tahun 2005, 2009, 2014 dan 2016

\subsection{Pemetaan Suhu Permukaan}

Pemetaan suhu permukaaan dilakukan dengan mengklasifikasi lokasi yang mempunyai suhu permukaan tanah kurang dari $30^{\circ} \mathrm{C}$ dan lebih besar dari $30^{\circ} \mathrm{C}$. Hal ini berdasarkan bahwa daerah potensi sebagai pulau panas bahang perkotaan mempunyai nilai suhu permukaan lebih besar dari $30^{\circ} \mathrm{C}^{(18)}$. Hasil deteksi suhu permukaan dapat dilihat pada Gambar 8. Peningkatan temperatur permukaan di tengah kota Bandung dan perluasan area yang mempunyai temperatur permukaan tanah lebih besar dari $30^{\circ} \mathrm{C}$ mulai terdeteksi pada tahun 2009. Perluasan area pulau panas perkotaan dimulai dari area panas di pusat kota Bandung meluas ke arah Utara (Lembang), ke arah Selatan di Bale Endah, Pacet, dan Majalaya. Perluasan ke arah Timur adalah di Cicalengka dan Nagreg, ke arah Barat di Cipatat dan Rajamandala. Data satelit yang digunakan tahun 2005, 2009, 2014 adalah hasil pemotretan di bulan Juli sedangkan tahun 2016 di bulan September. Pada bulan September di cekungan Bandung adalah musim hujan sedangkan bulan Juli adalah akhir musim kemarau. Perbedaan ini yang menyebabkan distribusi suhu permukaan di tahun 2016 nampak rendah dibandingkan tahun tahun sebelumnya. Jadi perubahan suhu permukaan yang memenuhi syarat untuk dianalisis adalah untuk tahun 2005, 2009, dan 2014 karena dipotret di musim yang sama yaitu di musim kemarau. Pada tahun 2009 mulai terdeteksi adanya hot spot di tengah kota, di Bandung Barat, Bandung Timur dan di Bandung Selatan. Pada tahun 2014 titik hotspot ini semakin meluas di kota Bandung, kota Cimahi, bagian Tenggara, bagian Timur dan Selatan cekungan Bandung.
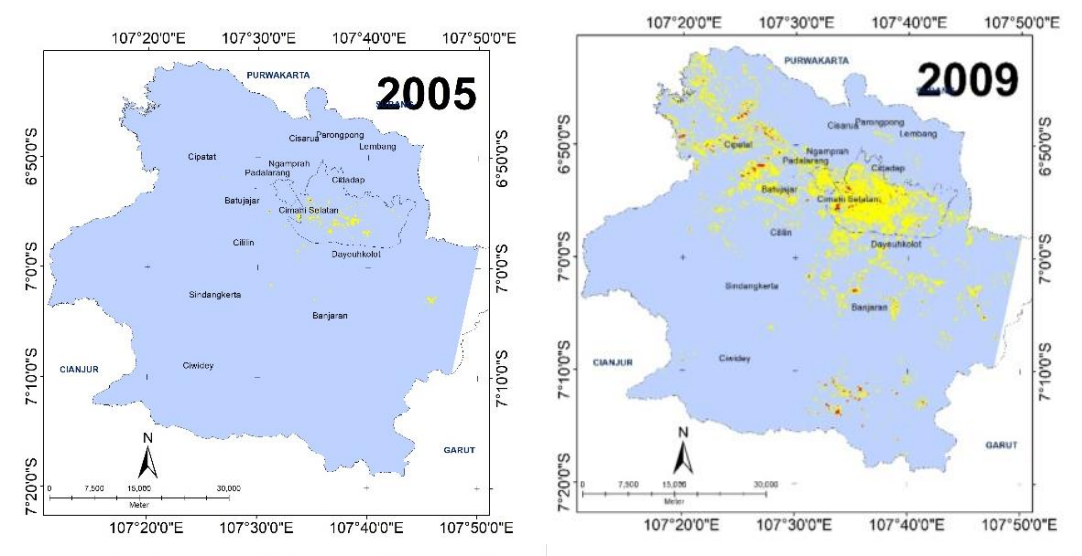

Legenda
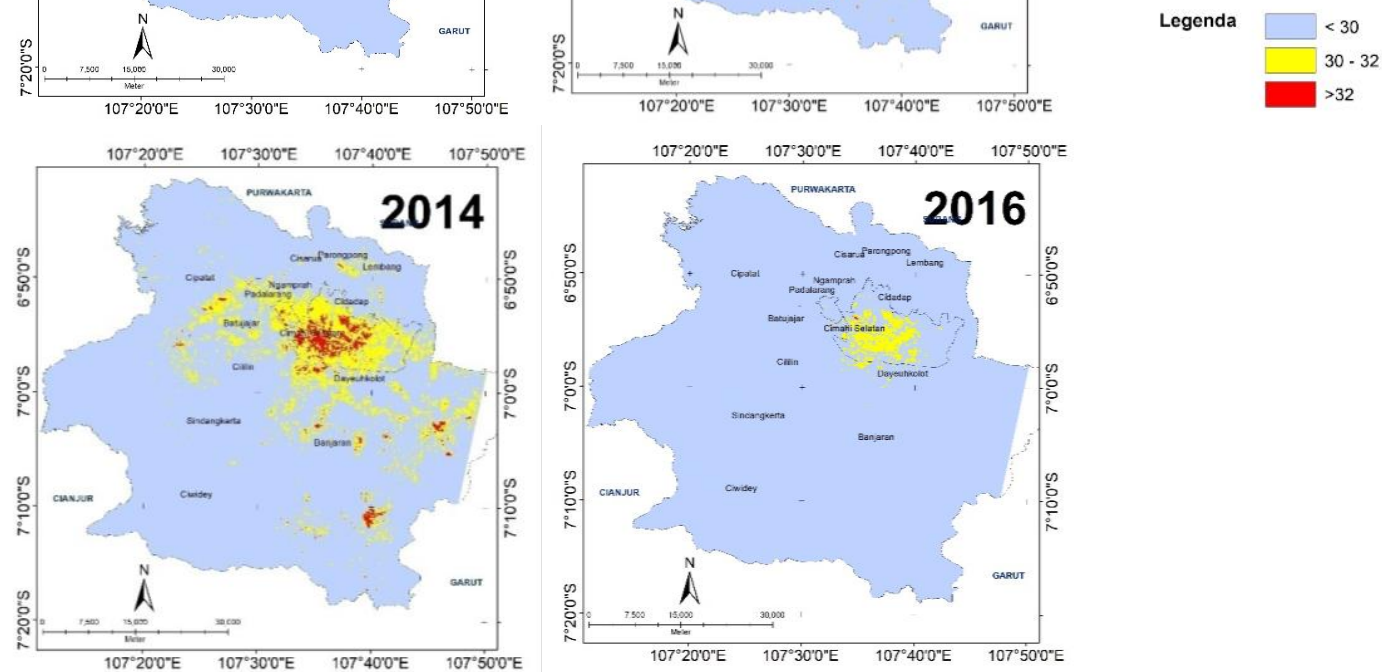

Gambar 8. Perkembangan pulau panas bahang perkotaan cekungan Bandung periode 2005, 2009 dan 2014 


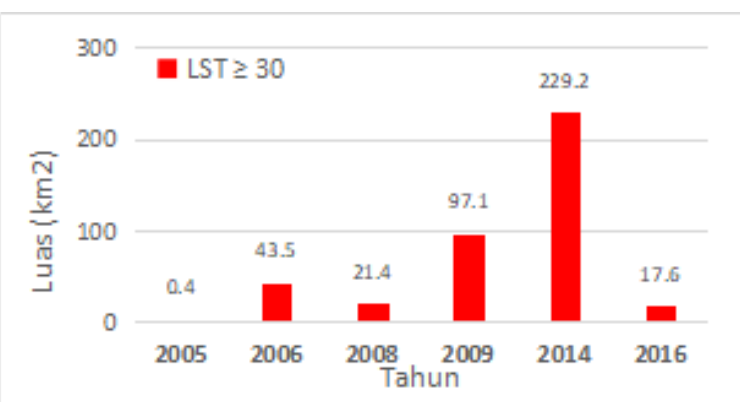

Gambar 9. Perkembangan luasan daerah suhu permukaan $>30^{\circ} \mathrm{C}$ di cekungan Bandung (2005 - 2016)

Gambar 8. menunjukkan adanya penambahan luasan daerah dengan suhu permukaan tanah lebih besar dari $30^{\circ} \mathrm{C}$. Pada tahun 2005 luasannya sebesar $0.40 \mathrm{~km}^{2}$, lalu pada tahun 2009 meningkat sebesar $97.076 \mathrm{~km}^{2}$ kemudian pada tahun 2014 meningkat seluas $229 \mathrm{~km}^{2}$. Penambahan luasan ini terkait dengan penambahan daerah pemukiman dan daerah industri di kota Bandung, perubahan daerah perkebunan menjadi tegalan di bagian Tenggara cekungan Bandung, perluasan daerah pemukiman di bagian Utara cekungan Bandung serta perkembangan pemukiman dan industri di bagian Barat cekungan Bandung. Berdasarkan deteksi perkembangan temperatur permukaan tanah menunjukkan adanya pusat perkembangan pulau panas perkotaan berada di pusat kota Bandung, Utara cekungan Bandung dan bagian Tenggara cekungan Bandung. Daerah panas tinggi di kota Bandung dan Utara Bandung sebagai akibat dari perkembangan daerah pemukiman/kota, sementara daerah panas tinggi yang terdeteksi di Tenggara cekungan Bandung yaitu di Pacet dan sekitarnya diakibatkan oleh adanya perubahan daerah perkebunan menjadi ladang/tegalan. Pusat perkembangan pulau panas tidak saja terjadi di pusat kota akan tetapi terjadi juga pada daerah tanah terbuka yang berupa ladang/tegalan. Perkembangan luasan dengan suhu permukaan lebih besar dari $30^{\circ} \mathrm{C}$ di cekungan Bandung ditandai dengan adanya peningkatan nilai albedo rata rata dan penurunan indeks vegetasi rata rata di cekungan Bandung

\section{KESIMPULAN}

Berdasarkan hasil penelitian diketahui bahwa telah terjadi pertambahan luasan daerah dengan suhu permukaaan di atas $30^{\circ} \mathrm{C}$ di cekungan Bandung. Perubahan ini terdeteksi dengan menggambarkan adanya perubahan dari albedo, variasi indeks kehijauan vegetasi, dan distribusi suhu permukaan tanah. Variasi indeks kehijauan vegetasi rata-rata di cekungan Bandung untuk periode 2005-2016 menunjukkan kecenderungan turun. Dalam periode penelitian (2005-2016) di cekungan Bandung terjadi peningkatan nilai albedo yang terkait dengan pengurangan daerah bervegetasi. Untuk periode 2005 - 2014 suhu permukaan di cekungan Bandung menunjukkan kecenderungan naik. Kecenderungan ini diduga sebagai akibat dari berkurangnya nya daerah bervegetasi, dan meningkatnya daerah dg albedo tinggi. Rata rata kenaikkan suhu permukaan tahun 2004 sampai tahun 2014 sebesar $1.3^{\circ} \mathrm{C}$. Pertambahan luas daerah dengan suhu permukaan lebih besar dari $30^{\circ} \mathrm{C}$ di cekungan diakibatkan oleh berubahnya daerah bervegetasi rapat menjadi daerah terbangun ataupun daerah terbuka. Dengan menggambarkan suhu permukaan yang mempertimbangkan emisivitas vegetasi dan emisivitas tanah maka kita dapat melakukan deteksi perkembangan daerah dengan suhu permukan lebih dari $30^{\circ} \mathrm{C}$ baik di daerah urban dan non-urban.

Area keberadaan dan perkembangan lokasi hot spot dapat di deteksi dan dianalisis. Lokasi daerah suhu permukaan tinggi tidak hanya terjadi di daerah urban (kota Bandung, dan Cimahi) akan tetapi terdeteksi pula di daerah ladang/tegalan di bagian Tenggara cekungan Bandung, Timur cekungan Bandung dan Barat Laut Batujajar yang merupakan daerah nonurban. Informasi ini sangat diperlukan oleh Pemerintah Daerah dalam mengendalikan tutupan lahan di cekungan Bandung sebagai salahsatu usaha mitigasi terhadap perubahan iklim.

\section{PERSANTUNAN}

Ucapan terima kasih penulis sampaikan kepada Pusat Penelitian Geoteknologi LIPI yang telah memberikan dukungan dana penelitian melalui DIPA tematik Tahun anggaran 2015. Terima kasih juga disampaikan kepada US Geological Survey (USGS) yang telah menyediakan data citra satelit Landsat Thematic Mapper (TM) 5 dan Landsat-8.

\section{DAFTAR PUSTAKA}

1. Carmin, J., Anguelovski, I., \& Roberts, D. (2012). Urban climate adaptation in the global south: planning in an emerging policy domain. Journal of Planning Education and Research, 32(1), 18-32.

2. Tokairin, T., Sofyan, A., \& Kitada, T. (2009). Numerical study on temperature variation in the Jakarta area due to urbanization. In The Seventh International on Conference of Urban Climate, http://www.ide.titech.ac.jp/ icuc7/extended abstracts/pdf/375851-1. 090515132251-004. pdf,(29 June 2012).

3. Voogt, J. A., \& Oke, T. R. (1997). Complete urban surface temperatures. Journal of applied meteorology, 36(9), 1117-1132. 
4. Voogt, J. A., \& Oke, T. R. (2003). Thermal remote sensing of urban climates. Remote sensing of environment, 86(3), 370-384.

5. Effat, H. A., \& Hassan, O. A. K. (2014). Change detection of urban heat islands and some related parameters using multitemporal Landsat images; a case study for Cairo city, Egypt. Urban Climate, 10, 171188.

6. Carmin, J., Nadkarni, N., \& Rhie, C. (2012). Progress and challenges in urban climate adaptation planning. Results of a global survey. Massachussetts Institute of Technology (MIT), Cambridge. Carter, JG, Cavan G., Connely A., Guy S., Handley J. and Kazmierczak A.(2015). Climate change and the city: Building capacity for urban adaptation. Progress in Planning, 95, 1-66.

7. Jauregui, E., \& Romales, E. (1996). Urban effects on convective precipitation in Mexico City. Atmospheric Environment, 30(20), 3383-3389.

8. Yu, X., Guo, X., \& Wu, Z. (2014). Land surface temperature retrieval from Landsat 8 TIRS-Comparison between radiative transfer equation-based method, split window algorithm and single channel method. Remote Sensing, 6(10), 9829-9852.

9. Tursilowati, L., Sumantyo, J. T. S., Kuze, H., \& Adiningsih, E. S. (2012). Relationship between urban heat island phenomenon and land use/land cover changes in JakartaIndonesia. Journal of Emerging Trends in Engineering and Applied Sciences, 3(4), 645653.

10. Rajeshwari, A., \& Mani, N. D. (2014). Estimation of land surface temperature of Dindigul district using Landsat 8 data. International Journal of Research in Engineering and Technology, 3(5), 122-126.

11. Ramdani, F., \& Setiani, P. (2014). Spatiotemporal analysis of urban temperature in Bandung City, Indonesia. Urban ecosystems, 17(2), 473-487.

12. Jatmiko, R. H., \& Hartono, B. P. D. (2016). Penggunaan Citra Saluran Inframerah Termal untuk Studi Perubahan Liputan Lahan dan Suhu sebagai Indikator Perubahan Iklim Perkotaan di Yogyakarta (Doctoral dissertation, Universitas Gadjah Mada).

13. Grover, A., \& Singh, R. B. (2015). Analysis of urban heat island (UHI) in relation to normalized difference vegetation index (NDVI): A comparative study of Delhi and Mumbai. Environments, 2(2), 125-138.

14. Taha, H. (1997). Urban climates and heat islands: albedo, evapotranspiration, and anthropogenic heat. Energy and buildings, 25(2), 99-103.
15. Weng, Q. (2001). A remote sensing? GIS evaluation of urban expansion and its impact on surface temperature in the Zhujiang Delta, China. International journal of remote sensing, 22(10), 1999-2014.

16. Weng, Q., Lu, D., \& Schubring, J. (2004). Estimation of land surface temperaturevegetation abundance relationship for urban heat island studies. Remote sensing of Environment, 89(4), 467-483.

17. Sobrino, J. A., Jiménez-Muñoz, J. C., \& Paolini, L. (2004). Land surface temperature retrieval from LANDSAT TM 5. Remote Sensing of environment, 90(4), 434-440.

18. Tursilowati, L. (2002). Urban heat island dan kontribusinya pada perubahan iklim dan hubungannya dengan perubahan lahan. In Seminar Nasional Pemanasan Global dan Perubahan Global. Fakta, mitigasi, dan adaptasi. Pusat Pemanfaatan Sains Atmosfer dan Iklim LAPAN, ISBN (pp. 978-979).

19. Myhre, G., \& Myhre, A. (2003). Uncertainties in radiative forcing due to surface albedo changes caused by land-use changes. Journal of Climate, 16(10), 1511-1524.

20. Statistik, B. P. (2015). Kota Bandung Dalam Angka 2015, 350.

21. Narulita, I., Rahmat, A., \& Maria, R. (2008). Aplikasi Sistem Informasi Geografi untuk Menentukan Daerah Prioritas Rehabilitasi di Cekungan Bandung. RISET Geologi dan Pertambangan, 18(1), 23-35.

22. Smith, R.B., 2010. The heat budget of the earth's surface deduced from spaceavailable on 